\title{
Flexural Behaviour of RC Beams with Recycled Aggregates
}

\author{
K. Ramadevi, M. Juhi Hephzibah Shalini
}

\begin{abstract}
Continuous raw material demand was increased in concrete productions which requires good quality and cost efficient alternative materials like Recycled Coarse Aggregate, $M$ Sand and Glass as aggregate. This paper reports the behaviour of concrete using Glass aggregate as Fine Aggregate and Recycled aggregate as Coarse Aggregate replacement in concrete up to $15 \%$ and $30 \%$ respectively. In this project work, the concrete grade M25 was selected and IS method was used for mix design. The properties of Cement, M-Sand, Natural Coarse Aggregate, Glass asAggregate and Recycled Aggregate were investigated. The Beam Specimens were casted with and without $C \& D$ waste (Coarse Aggregate Replaced with Recycled Aggregate at 30\% and Fine Aggregates replaced with Glass Aggregate at 15\%). Vibration Analysis were made by using FFT analyser to determine acceleration characteristics. The work is focused on possible conservation of natural resources by substituting with waste material by suggesting a possible reuse option for Construction waste.
\end{abstract}

Key words: C\&D Waste, Recycled Aggregate, Glass Powder, and Vibration Analysis, FFT analyzer.

\section{INTRODUCTION}

Coimbatore city Municipal Corporation says that population of the city is 10.09 lakhs and the quantity of garbage generated is $601 \mathrm{MT} /$ day which includes debris concrete, steel, glass, plastic waste, broken concrete etc. Buildings demand more materials and our energy, but they also produce waste. The waste due to construction and destruction are generated during the construction, repair and disposal phases of a building. This includes waste from wrecked constructions, the renovations and wastes due to repair. Nowadays more attention is dedicated on the environment issues on waste and protection of natural resources like natural aggregates and reusing of wastes materials.

During recent years, consciousness regarding environmental atrocity has increased due to the iinterest of construction community in utilizing waste or recycled materials in concrete has also aggravated. If we see around us, we can see so many materials we consider waste which rather must be opportunities. When glass waste is crushed it is like natural river sand since it is made from silica and it shows properties of an aggregate material.

\section{OBJECTIVES}

$>$ To collect and process aggregates from C\&D waste.

Revised Manuscript Received on 14 August, 2019.

Dr. K. Ramadevi, Associate Professor, Department of Civil Engineering,Kumaraguru College of Technology, Coimbatore, Tamilnadu, India.

Ms.M.Juhi Hephzibah Shalini, M.E (Structural Engineering), Civil Engineering Department, Kumaraguru College of Technology, Coimbatore, Tamilnadu, India.
To examine the physical properties of glass aggregate and recycled aggregate, compare the test results with river sand, M-sand and natural aggregates respectively.

$>$ To Study the compression and of cement by utilising waste glass in various percentages $(0 \%, 5 \%$, $10 \%, 15 \%$, and $20 \%$ ) as replacement for fine aggregates.

\section{MATERIALS USED}

\section{i) Cement}

OPC of 53 grade confining to (IS12269-2013) was used throughout the work. The results of tests done to determine the mechanical properties of the cement indicated its suitability for concrete works. The cement satisfies the requirement of IS: 8112-1989 The physical properties of the cement used in this investigation are shown in Table 1

Table 1 Physical Properties of Cement

\begin{tabular}{|l|l|l|}
\hline Test conducted & Result & Requirements \\
\hline Fineness & $8 \%$ & Not exceed $10 \%$ \\
\hline Specific Gravity & 3.1475 & 3.10 to 3.15 \\
\hline Consistency & $33 \%$ & $26 \%$ to $33 \%$ \\
\hline $\begin{array}{l}\text { Setting time } \\
\text { (Initial) }\end{array}$ & 75 minutes & $\begin{array}{l}\text { Shall not be less } \\
\text { than } 30 \text { minutes }\end{array}$ \\
\hline
\end{tabular}

ii) fine aggregate

a) Natural Aggregates

River sand and M-sand passing through $4.75 \mathrm{~mm}$ IS sieve were obtained from local supplier.

\section{b) Glass Powder}

Waste glass were produced while demolition of buildings. Glass waste is found to be a very hard material. Glass waste has to be powdered to required size prior to adding in concrete. In this experiment, glass powder having particle size less than $2.36 \mathrm{~mm}$ was used.

Table 2 presents the physical properties of the fine aggregate used in this investigation. 
Table 2 Result of physical properties of the Fine Aggregate

\begin{tabular}{|l|l|l|l|}
\hline \multirow{2}{*}{$\begin{array}{l}\text { Test } \\
\text { conducted }\end{array}$} & \multicolumn{2}{|l|}{ Sample } & \multirow{2}{*}{ Requirement } \\
\cline { 2 - 4 } & M-Sand & $\begin{array}{l}\text { Glass } \\
\text { Powder }\end{array}$ & \\
\hline $\begin{array}{l}\text { Fineness } \\
\text { modulus }\end{array}$ & 3.11 & 2.65 & 2.2 to 3.2 \\
\hline $\begin{array}{l}\text { Water } \\
\text { absorption }\end{array}$ & $1.9 \%$ & $0.9 \%$ & $0.5 \%$ to $2.0 \%$ \\
\hline $\begin{array}{l}\text { Specific } \\
\text { Gravity }\end{array}$ & 2.63 & 2.63 & 2.4 to 2.7 \\
\hline $\begin{array}{l}\text { Moisture } \\
\text { content }\end{array}$ & Nil & Nil & Less than $1 \%$ \\
\hline
\end{tabular}

iii)Coarse Aggregates

\section{a) Coarse Aggregate From Natural Resources}

Aggregates obtained from crushed granite of size passing through $20 \mathrm{~mm}$ and retained on $4.75 \mathrm{~mm}$ I.S sieve as per IS: 383 - 1970 was used as aggregates.

\section{b) Recycled Coarse Aggregate}

Recycled aggregate was collected from waste concrete waste (washed in water) passing through $20 \mathrm{~mm}$ and retained on $4.75 \mathrm{~mm}$ I.S sieve as per grading requirements of IS: 2386 - 1983 were used as recycled coarse aggregate.

Table 3 presents the test results of physical properties of the coarse aggregate used in this investigation. The designations adopted are Sample 1 (Natural Aggregate) and Sample 2 (Recycled Aggregate).

Table 3 Result of Physical Properties of the CA

\begin{tabular}{|l|l|l|l|}
\hline \multirow{2}{*}{$\begin{array}{l}\text { Test } \\
\text { Conducted }\end{array}$} & \multicolumn{2}{|l|}{ Samples } & \multirow{2}{*}{ Requirement } \\
\cline { 2 - 4 } & $\mathbf{1}$ & $\mathbf{2}$ & \\
\hline $\begin{array}{l}\text { Water } \\
\text { Absorption }\end{array}$ & $0.8 \%$ & $0.4 \%$ & $0.1 \%$ to $2.0 \%$ \\
\hline $\begin{array}{l}\text { Moisture } \\
\text { Content }\end{array}$ & Nil & Nil & Less than 1\% \\
\hline $\begin{array}{l}\text { Crushing } \\
\text { Strength Test }\end{array}$ & $25.7 \%$ & $27.6 \%$ & $\begin{array}{l}\text { Not More than } \\
30 \%\end{array}$ \\
\hline $\begin{array}{l}\text { Aggregate } \\
\text { Impact Value }\end{array}$ & $30 \%$ & $31 \%$ & $\begin{array}{l}\text { Not More than } \\
45 \%\end{array}$ \\
\hline
\end{tabular}

\section{CONCRETE MIX DESIGN}

Mix design as per IS: 10262 - 2009 for M25 grade concrete was done and the results are presented in Table 4.

Table 4 Concrete Mix Design

\begin{tabular}{|l|l|l|l|l|}
\hline Weight & W/c & Cement & FA & CA \\
\hline $\mathrm{Kg} / \mathrm{m}^{3}$ & 190 & 420 & 692 & 1143 \\
\hline Ratio & 0.45 & 1 & 1.64 & 2.71 \\
\hline
\end{tabular}

\section{EXPERIMENTAL INVESTIGATION}

Two number of beam specimens were cast and tested for flexure up to failure. These beams were cast for a span of $1.5 \mathrm{~m}$, with simple supports and tested against two-point loading. Loads and corresponding deflections were recorded at the mid span and at 1/3rd of the span using analog dial gauges. Vibration Analysis of the casted RC Beams was done using Fast Fourier Transformer (FFT) analyzer was done.

HYSD steel bars of diameter $10 \mathrm{~mm}$ as the longitudinal reinforcement in the flexure zone and $8 \mathrm{~mm}$ diameter bars were used in the compression zone of the RC beam specimens. Vertical stirrups, 2 legged of $6 \mathrm{~mm}$ diameter at a spacing of $200 \mathrm{~mm}$ (at mid span) and $120 \mathrm{~mm}$ (at supports) center to center was provided as shear reinforcement.

The test specimen was cast in steel moulds. The raw materials were weighted accurately. The concrete was mixed thoroughly in dry condition in a concrete mixer. The lubricated oil was applied in the cast iron moulds. To ensure uniform mixing, 3 to 5 minutes mixing time was given. Then steel bars were tied and kept in to the mould. Fresh concrete is discharged into the beam mould in three layers, each layer was properly compacted.

After 24 hours, the specimens were removed from moulds and prepared for curing with potable water using gunny bags for 28 days. The test specimen was mounted in a Loading frame of 100T Capacity. The ends of the beam was rested on simple supports. The load was applied at two locations each $500 \mathrm{~mm}$ away from center of the beam headed towards the support.

Analog dial gauges with least count of $0.01 \mathrm{~mm}$ were used for measuring deflections under $1 / 3 \mathrm{rd}$ points and at mid span. Deflections were noted for corresponding loads until failure occurred. During testing, the performance of the beam was witnessed carefully. The first crack load, ultimate load and deflection at ultimate load were noted for both beams. Figure 1 shows the formation of cracks in the beam under testing.

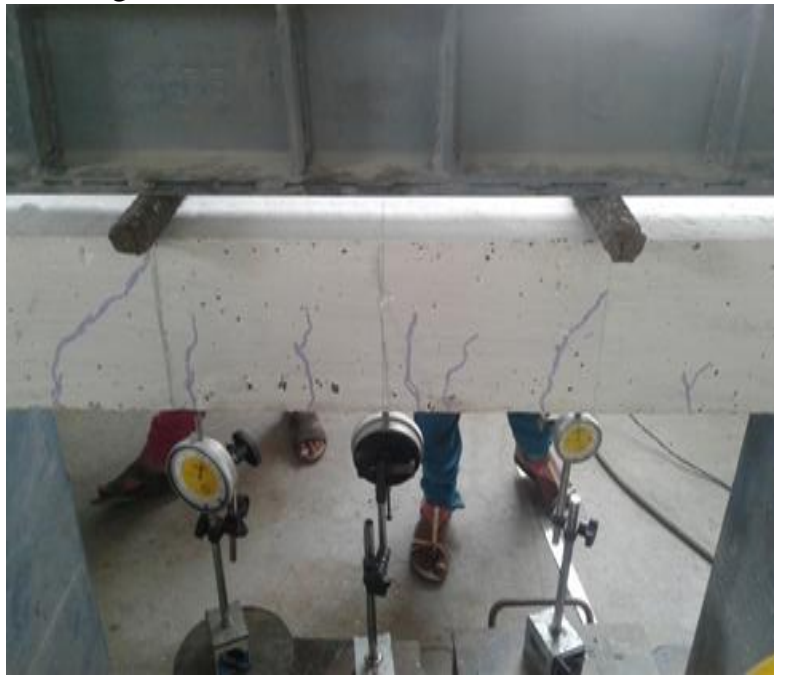

Fig 1 Crack formation in the RC Beam

Published By:

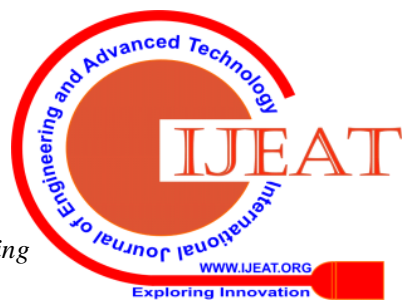




\section{VIBRATION ANALYSIS OF RC BEAMS}

Beams comprising of both Conventional Concrete and EWaste were tested under Vibration Analyzer Instrument and Frequency range for the RC beams was determined. Catastrophic failures indicate Cracks in the vibrating components. Hence, it is necessary to know the dynamics of cracked structures. Stiffness degradation of the structure occurs due to damage in a structure, and hence the natural frequencies of the structure also reduces consequently. Fast Fourier Transformer (FFT) Algorithm is used for measurement and indicative of vibration. The FFT Analyzer is a PC based virtual instrument. The location of natural frequency is represented by the peaks in the frequency response spectrum. The frequency curve was obtained using NVGATE software. Figure 1 shows the testing of RC beam using FFT analyzer.

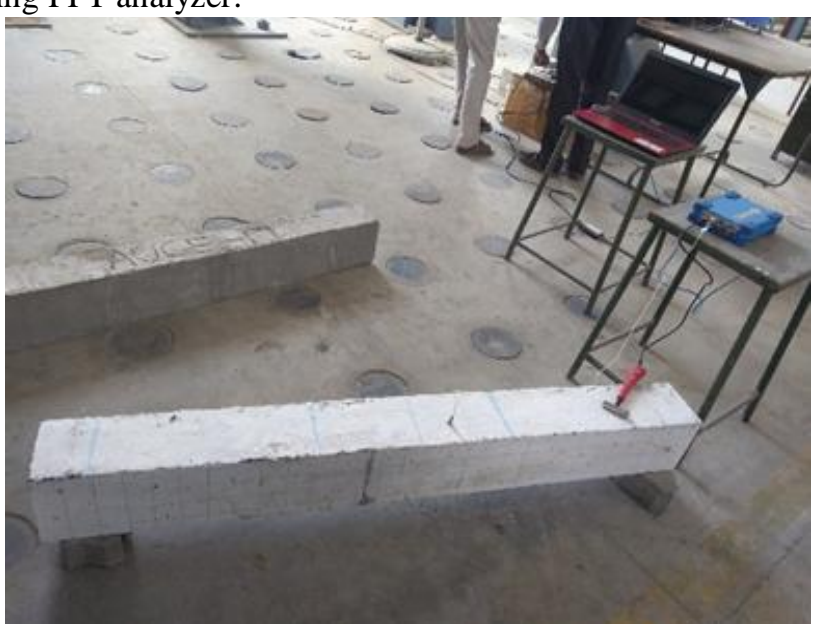

Fig.2.Testing of C\&D-Waste Beam using FFT Analyzer

\section{RESULT AND DISCUSSION}

\section{a) LOAD DEFLECTION BEHAVIOUR OF RC BEAMS}

The RC Beams of Conventional Concrete and $30 \%$ replacement of reusable aggregate by coarse aggregate $(15 \%$ replaced with glass powder as fine aggregate) were tested and Load - Deflection Behaviour of beams is represented in the following Figures 3 and 4.

Table 5 presents the test results of RC Beams with natural aggregates and RC beam with $30 \%$ recycled coarse aggregate under flexure.

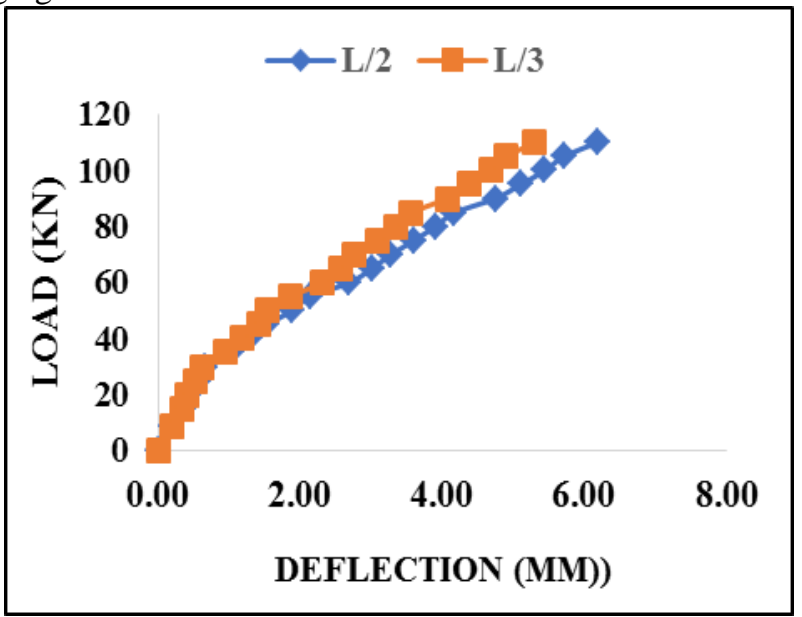

Fig 3. Load deflection behaviour on conventional concrete

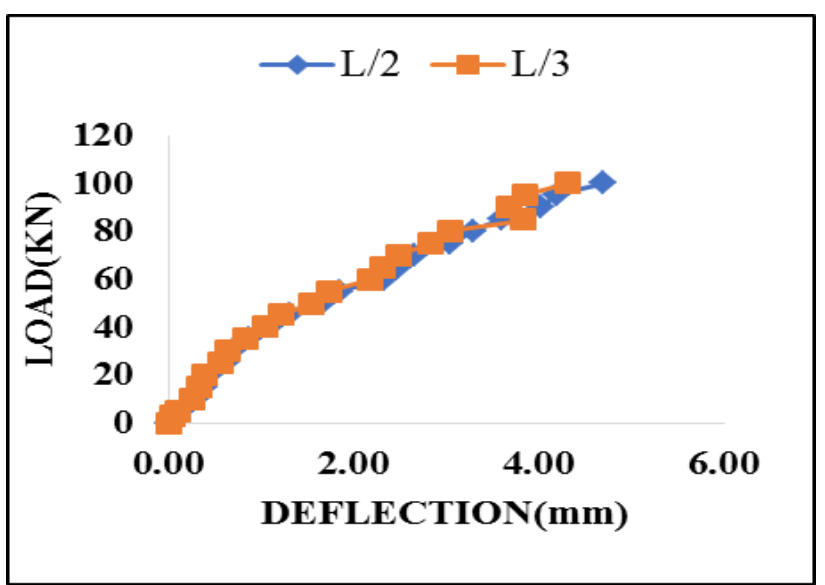

Fig 4. Load deflection behaviour on $30 \%$ replacement of C\& D waste

Table 5 Test Results of Beams

\begin{tabular}{|l|l|l|}
\hline Beam Test parameters & CM & M-30 \\
\hline First Crack Load (kN) & 45 & 40 \\
\hline Ultimate Load (kN) & 130 & 100 \\
\hline $\begin{array}{l}\text { Initial stiffness of the Beam } \\
\text { (kN/mm) }\end{array}$ & 47.37 & 50 \\
\hline $\begin{array}{l}\text { Stiffness at Ultimate Load } \\
\text { (kN/mm) }\end{array}$ & 15.19 & 21.28 \\
\hline $\begin{array}{l}\text { Stiffness from Graph } \\
\text { (kN/mm) } \quad 16.33\end{array}$ & 21.01 \\
\hline
\end{tabular}

b) Vibration Analysis OfRc Beams

The test results of vibration analysis with frequency and acceleration variations is shown in Table 6.

Table 6 Vibration Analysis Results

\begin{tabular}{|l|l|l|}
\hline $\begin{array}{l}\text { Specimen } \\
\text { ID }\end{array}$ & $\begin{array}{l}\text { Frequency } \\
(\mathbf{k N m})\end{array}$ & $\begin{array}{l}\text { Acceleration } \\
\left(\boldsymbol{\mu m} / \mathbf{s}^{2}\right)\end{array}$ \\
\hline Control mix & 4.087 & 174.4 \\
\hline M-15- 30 & 2.55 & 67.7 \\
\hline
\end{tabular}

\section{CONCLUSIONS}

For the same load the M-15-30 Beam indicated $5.76 \%$ higher deflection than that of Conventional RC Beam.

In the RC Beam Tests, the Ultimate Load Carrying Capacity for M-15-30 Beam is $100 \mathrm{kN}$ which is $23.07 \%$ less than that of Conventional RC Beam.

$>\quad$ The first crack load for M-15-30 beam is found to be $40 \mathrm{kNwhich}$ is less than $11.11 \%$ of Conventional $\mathrm{RC}$ Beam. This is due to the presence of recycled aggregate.

$>\quad$ Moreover, Stiffness of $30 \%$ replacement of coarse aggregate with recycled aggregate beam higher than the Conventional RC Beam.

In the Vibration Analysis Test, the Frequency range of M-15-30 RC Beam is lesser than the Conventional $\mathrm{RC}$ beam. 
Moreover, the Acceleration of Conventional RC Beam is more than the M-15-30 RC Beam

\section{REFERENCES}

1. Mohd Monish, Vikas Srivastava, V.C. Agarwal, P.K. Mehta and Rakesh Kumar, "Demolished waste as coarse aggregate in conctrete". Research Gate, Vol.1 Issue 09, February 2013.

2. Angha Kalpavalli, Dr. S. Naik, "Use of Demolished Concrete Wastes as Coarse Aggregates in High Strength Concrete Production". International Journal of Engineering Research \& Technology (IJERT), Vol.4 Issue 07, July 2015.

3. A.N.Dabhade and Dr.S.R.Choudhari et al., " Performance Evaluation Of Recycled Aggregate Used In Concrete " International Journal of Engineering Research and Applications (IJERA), Vol. 2, Issue 4, July-August 2012.

4. M. Adaway \& Y. Wang," Recycled glass as a partial replacement for fine aggregate in structural concrete Effects on compressive strength ". Electronic Journal of Structural Engineering Vol.14 Issue 9,2015 .

5. M. Iqbal Malik, Muzafar Bashir et al.," Study of Concrete Involving Use of Waste Glass as Partial Replacement of Fine Aggregates" IOSR Journal of Engineering (IOSRJEN), Vol. 3, Issue 7 July 2013.

6. K. I. M. Ibrahim, " The Effect of Using Waste Glass [WG] as Partial Replacement of sand on Concrete". Journal of Mechanical and Civil Engineering (JMCE) Vol. 14, Issue 2, April 2017

7. S.P. Gautam, Vikas Srivastava and V.C. Agarwal." Use of glass wastes as fine aggregate in Concrete ". J. Acad. Indus. Res. (JAIR), Vol.1 Issue 6, November 2012.

8. Vikas Srivastava, S. P. Gautam, V. C. Agarwal, P. K. Mehta," Glass Wastes as Coarse Aggregate in Concrete ". Journal of Environmental Nanotechnology, Vol.3 Issue 1,19 January 2016

9. Zainab Z. Ismail *, Enas A. AL-Hashmi," Recycling of waste glass as a partial replacement for fine aggregate in concrete". ELSVIER, Vol 19 Issue 4, 10 October 2008.

10. Dr. R. Kumutha, Prof. K. Vijai, " Effect of Recycled Coarse Aggregates in Properties of Concrete". Journal of Green Building: Fall, Vol. 3, No. 4, 2008.

11. M. Etxeberria A. R. Mar? E. Vázquez, "Recycled aggregate concrete as structural material". Materials and Structures, Vol.3 Issue 07, 13 July 2006.

12. Pawel Sikora , Adrian Augustyniak et al.," Characterization of Mechanical and Bactericidal Properties of Cement Mortars Containing Waste Glass Aggregate and Nanomaterials". National Center for Biotechnology Information (NCBI), Vol. 9 Issue 8, August 2016.

13. N. Tamanna, N. Mohamed Sutan,I et al., " Strength Characteristics of Mortar Containing Different Sizes Glass Powder ". e-Journal of Civil Engineering: Vol 5, Issue 117 November 2016.

14. Sumaiya Binte Huda, M. Shahria Alam," Mechanical behavior of three generations of $100 \%$ repeated recycled coarse aggregate concrete". ResearchGate, August 2014.

15. Kumutha, R. and Vijai, K., "Strength of Concrete Incorporating Aggregates Recycled from Demolition Waste". ARPN Journal of Engineering and Applied Sciences, Vol. 5, Issue 2, 21 May 2015.

16. Tan Li a,b , Jianzhuang Xiao et al.," Experimental study on mechanical behaviors of concrete with large-size recycled coarse aggregate". ELSVIER Vol 120 Issue 1 ,10 September 2016.

17. CORINALDESI Valeria and MORICONI Giacomo," Evaluation of Recycled Aggregate Concrete Cracking through Ring Test". Applied Mechanics and Materials Vols. 174-177, 2012/May 2014.

18. Shahiron Shahidana, Mohamad Azim Mohammad Azmib et al.," Utilizing Construction and Demolition (C\&D) Waste as Recycled Aggregates (RA) in Concrete ". ELSVIER, 2016

19. Rakesh Kumar, "Comparative Study on Carbonated and Non-Carbonated Recycled Aggregate Concrete with Glass Powder as Partial Replacement for OPC". International Journal of Engineering and Science (IJES), Vol. 5, Issue 4, November 2017.

20. M. C. Limbachiya, T. Leelawat et al.,"Use of recycled concrete aggregate in high-strength concrete". Materials and Structures, Vol. 33, November 2000. 